\title{
The youth are coming. A new image of female and male nurses
}

\author{
To idzie młodość. Nowy wizerunek pielęgniarek i pielęgniarzy
}

Marzena Sobczak, Anna Skuzińska

Elbląska Uczelnia Humanistyczno Ekonomiczna

AUTOR DO KORESPONDENCJI/CORRESPONDING AUTHOR:

Marzena Sobczak

ul. Obrońców Pokoju 13/20, 82-300 Elbląg e-mail: sobczakmarzena@wp.pl

STRESZCZENIE

Słowa kluczowe:

ABSTRACT

Key words:

\section{IO IDZIE MRODOŚC. NOWY WIZERUNEK PIELEZGNIAREK I PIELEZGNIARZY}

Cel pracy. Główny cel niniejszej pracy stanowiło określenie poziomu kompetencji społecznych studentów pielęgniarstwa na przykładzie studentów I roku Elbląskiej Uczelni Humanistyczno - Ekonomicznej oraz odpowiedź na pytanie jakie motywy skłaniają adeptów zawodu do podjęcia studiów.

Materiał i metodyka. W badaniu uczestniczyło $n=217$ studentów pielęgniarstwa I roku Elbląskiej Uczelni HumanistycznoEkonomicznej rozpoczynających naukę w latach 2013-2015. Do przeprowadzenia badań zastosowano metodę sondażu diagnostycznego. Narzędzia badawcze stanowiły kwestionariusze ankiet: kwestionariusz autorski, Kwestionariusz Wrażliwości Empatycznej autorstwa M. Kaźmierczak, M. Plopa, S. Retowski oraz Kwestionariusz Zachowań Asertywnych autorstwa M. Sobczak opracowany w oparciu 0„Mapę asertywności” zawartą w książce Marii Król-Fijewskiej.

Wyniki. Studenci poszczególnych roczników różnią się istotnie w poziomie empatii i asertywności. Osoby nie posiadające dotychczas zawodu medycznego wykazują się istotnie wyższym poziomem asertywności niż osoby posiadające już inny zawód medyczny. Zaobserwowano istotne statystycznie różnice w podskalach kwestionariusza Wrażliwości Empatycznej między badanymi studentkami i studentami. Najczęściej wskazywanym motywem podjęcia studiów przez badanych była pomoc innym oraz pewność zatrudnienia i świadomy wybór posiadania drugiego zawodu.

Wnioski. Osoby podejmujące studia na kierunku pielęgniarstwo nie w pełni wpisują się w aktualnie funkcjonujący wizerunek pielęgniarek. Zróżnicowane motywy podejmowania nauki, inne zasoby kompetencji społecznych przystępujących do zawodu osób mogą sprawić, że ich spojrzenie na pielęgniarstwo i jego problemy będzie inne niż funkcjonujące dzisiaj. Kwestia poznania nowego oblicza polskich pielęgniarek i pielęgniarzy, sposób w jaki wejdą w życie zawodowe staje się więc wyzwaniem, które może zmienić także obraz samego zawodu.

pielęgniarstwo, empatia, asertywność

\section{THE YOUTH ARE COMING. A NEW IMAGE OF FEMALE AND MALE NURSES}

Aim. The aim of this research study was to determine the level of social competence of nursing students basing on the example of the first-year students of Elblag University of Humanities and Economy. Additionally, the aim was to find out why candidates choose nursing studies.

Material and methods. 217 nursing students starting their education at Elblag University of Humanities and Economy between the years 2013 and 2015 participated in the research. In order to conduct the research, the authors used a survey. The research tools included the questionnaires: the authors' questionnaire, the questionnaire of empathy compiled by M. Kaźmierczak, M. Plopa, S. Retowski, and the questionnaire of assertive behaviour compiled by M. Sobczak basing on "Assertiveness Map" included in Maria Król-Fijewska's book.

Results. Students of different years differ substantially as far as the level of empathy and assertiveness is concerned. People who have no nursing-related education show a much higher level of assertiveness than the people who have a similar medical profession. The substantial statistical differences between the female and male students taking part in the research were observed as far as the subscales of the questionnaire of empathy is concerned. The most common reason for choosing the studies was the need to help other people, job security and a conscious choice of having another profession.

Conclusions. People who decide to study nursing do not fully reflect the contemporary image of a nurse. The various reasons for choosing that particular profession, different resources of social competence of those who enter the profession may make them perceive nursing and its problems in a different way from the one that is present nowadays. The issues of becoming familiar with the new image of Polish female and male nurses, the way in which they start their professional life become a challenge which may change the image of the profession itself.

nursing, empathy, assertiveness 


\section{INTRODUCTION}

Working as a nurse should be based on a deep understanding of the needs of other people. However, prospective students of nursing come from completely different backgrounds, when compared with those who started their nursing education at secondary school level and today are counted among the representatives of the so-called „ middle-aged Polish nurse” group.

\section{AIM}

The main aim of this research was to determine the level of social competence of nursing students basing on the example of the first-year students of Elbląg University of Humanities and Economy and to find out what makes candidates choose nursing studies.

\section{MATERIALS AND METHODS}

217 first-year nursing students starting their education at Elbląg University of Humanities and Economy between years 2013 and 2015 participated in the research.

In order to conduct the research, the authors used the method of a diagnostic survey. The research tools included the questionnaires were the authors' questionnaire, the Questionnaire of Empathic Sensitivity compiled by M. Kaźmierczak, M. Plopa, S. Retowski [1] and the Questionnaire of Assertive Behaviors compiled by M. Sobczak and based on "Assertiveness Map" included in Maria Król-Fijewska’s book [2].

\section{RESULTS}

A detailed analysis using the U Mann-Whitney test revealed significant differences in terms of Empathic Concern (EMP_TROSKA) between the students of years 2013 and 2015, and years 2014 and 2015. The students of the year 2015 obtained significantly higher score $(\mathrm{p}<0.001)$. In terms of Empathic Unpleasantness (EMP_PRZYKR) significant differences were revealed between the students of years 2014 and 2015 - the students of the year 2014 obtained the higher score. A little statistical difference was observed in these terms between years 2013 and 2015 $(\mathrm{p}=0.059)$. The students of the year 2015 obtained a higher score. In terms of subscale of Acceptance of Perspective (EMP_PERS) significant differences were found between years 2013 and 2015 and years 2014 and 2015. The year 2015 gained higher scores in these terms $(p<0.001$ in both relations).

In terms of assertiveness there is a statistically little difference between years 2013 and $2014(\mathrm{p}=0.084)$. Students from the year 2013 have a slightly higher score on a scale of assertiveness.

To study the relations between the reason for choosing the studies and the level of empathy and assertiveness, nonparametric Mann-Withney test was used.

People who chose the reason of "need to help other people" differed significantly in terms of Acceptance of Perspective variable (EMP_PERS) gaining higher scores than those who did not choose this reason $(U=4479$, $\mathrm{p}<0.01)$.

People choosing nursing as a profession due to the job security reported significantly lower levels of Empathic Concern variable (EMP_TROSKA) than those who did not choose this reason $(U=4573$; $=0,01)$.

Tab. 1. Characteristics of the group of respondents in terms of a year of starting the studies and their profession.

\begin{tabular}{|l|c|c|c|}
\hline \multirow{2}{*}{ Job experience } & \multicolumn{3}{|c|}{ Year of starting the studies, the number of students } \\
\cline { 2 - 4 } & $\mathbf{2 0 1 3}$ & $\mathbf{2 0 1 4}$ & $\mathbf{2 0 1 5}$ \\
\hline Medical profession & 25 & 32 & 37 \\
\hline Non medical profession & 19 & 18 & 28 \\
\hline Without profession & 26 & 22 & 25 \\
\hline Total & 70 & 72 & 90 \\
\hline
\end{tabular}

Tab. 2. The level of assertiveness of the respondents.

\begin{tabular}{|c|c|c|c|c|c|}
\hline 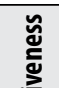 & N & minimum & maximum & $\begin{array}{c}\text { Average } \\
\text { (Raw results) }\end{array}$ & $\begin{array}{l}\text { Standard } \\
\text { deviation }\end{array}$ \\
\hline 气ू̆ & (Raw results) & $\begin{array}{l}\text { Standard } \\
\text { deviation }\end{array}$ & 155.00 & 105.5380 & 9.8412 \\
\hline
\end{tabular}

Tab. 3. The level of empathy of the respondents.

\begin{tabular}{|l|c|c|c|c|c|}
\hline \multicolumn{1}{|c|}{$\begin{array}{c}\text { Empathy: } \\
\text { subscales }\end{array}$} & $\mathbf{N}$ & minimum & maximum & $\begin{array}{c}\text { Average } \\
\text { (sten) }\end{array}$ & $\begin{array}{c}\text { Standard } \\
\text { deviation }\end{array}$ \\
\hline Empathic concern & 204 & 1.00 & 10.00 & 4.1275 & 2.0852 \\
\hline $\begin{array}{l}\text { Empathic } \\
\text { unpleasantness }\end{array}$ & 204 & 1.00 & 10.00 & 4.2304 & 1.6963 \\
\hline $\begin{array}{l}\text { Acceptance } \\
\text { of perspective }\end{array}$ & 204 & 1.00 & 10.00 & 5.2304 & 1.8677 \\
\hline
\end{tabular}

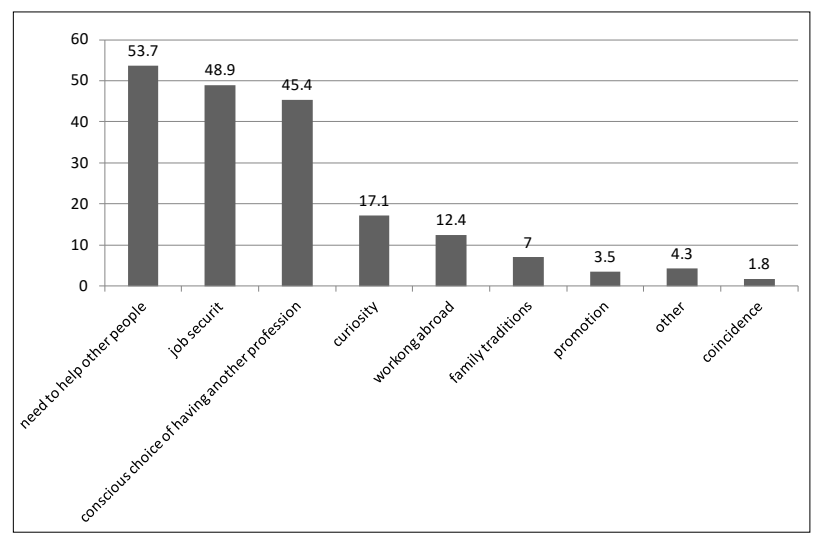

Fig 1. Reasons for choosing the profession n-217. Response rate.

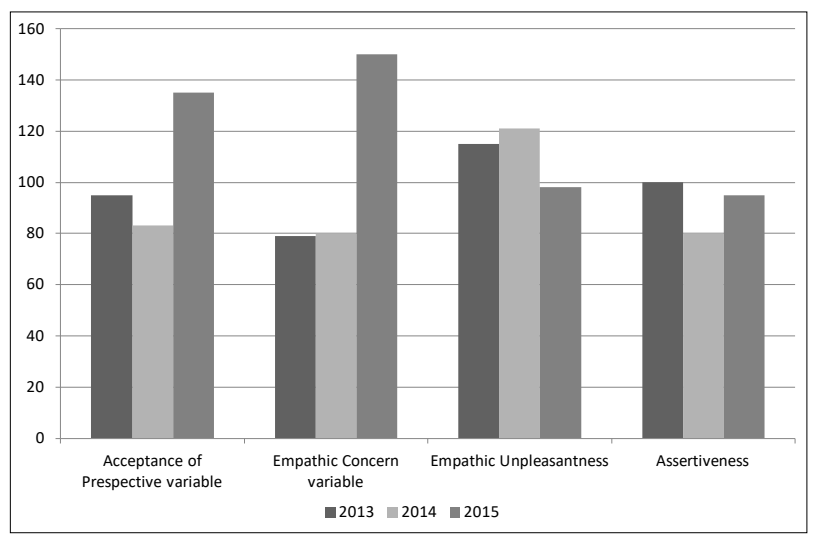

Fig 2. Differences in the level of empathy and assertiveness among the students of the years 2013,2014 and 2015. 
In case of the reason of „conscious choice of having another profession." people pointing to this reason gain a slightly lower level of Acceptance of Perspective (EMP_PERS) than those who don't choose this reason ( $\mathrm{U}=4739.5, \mathrm{P}=0.073)$.

People who choose the nurse profession because of the reason of "Family traditions" gain a significantly higher level in terms of Empathic Concern variable (EMP TROSKA) than people who don't choose this reason $(\mathrm{U}=871,5 ; \mathrm{p}<0,05)$.

Students who gave the reason of ,'Coincidence" for choosing studies are characterized by a significantly higher level of Empathic Concern (EMP_TROSKA) than those who did not choose this reason $(U=61, p=0.081)$.

\section{Report}

The respondents choosing nursing studies at the Elbląg University of Humanities and Economics (EUH-E) in 2013-2015 were a different group than those classified in the so-called „middle-aged Polish nurse" group , who were examined so far by the authors. Many of today's students already have a profession, it is often a different medical profession such as a medical rescue worker, a medical caretaker or a midwife. There are also people with occupations unrelated to medicine such as an economist, an educator and a sociologist. The need for helping other people remains the most common reason for choosing the profession. Both young students of nursing and nurses aged around 48 years old today point to that reason [3].

Respondents assertiveness in terms of the average results is higher than the EUH-E students who were surveyed in 2009 and were studying extramural second degree nursing, physiotherapy and emergency medical services [4]. Of course, assertiveness is not a one-dimensional phenomenon and only the analysis of individual spheres of assertiveness such as expressing our own feelings, defending our own rights and the tendency to violate other people's boundaries can provide some more information about the differences between the respondents.

The empathy of the surveyed students in terms of Empathic Concern and Empathic Unpleasantness does not differ from the empathy of the previously surveyed nurses, where the same tool was used $[5,6,7,8,9]$, and it reaches average values. The scale of Empathic Concern assesses with the tool constructed by the authors of the Questionnaire of Empathic Sensitivity [2] the ability of empathy and compassion for people affected by failure. Empathic Unpleasantness concerns the feeling of unpleasant sensations and discomfort associated with watching the suffering of others.

Both Empathic Concern and Empathic Unpleasantness are emotional dimensions of empathy. On the other hand, Acceptance of Perspective concerns the tendency to take other people's point of view in everyday situations and it relates to the cognitive aspect of empathy. [2] The dimension of Acceptance of Perspective among the nurses surveyed in 2011 [5,6] reached high levels, while it reached average values among the people currently star- ting the studies. The results of the research show some interesting, statistically significant differences concerning the levels of empathy among the students of EUH-E from years 2013, 2014 and 2015. The students starting their education in the academic year 2015/2016 showed a higher level of Empathic Concern and Acceptance of Perspective than the students of previous years. Perhaps it has some relation with previous professional experiences of these people. The obtained results also show that the reasons for choosing the profession, like „a need to help other people” or „family traditions" have a significant relationship with the empathy in terms of Acceptance of Perspective (EMP_PERS). People mentioning this as a reason achieved significantly higher scores in this area. Students who pointed out the economic reasons for choosing the profession such as "Job security” or „Conscious choice of having another profession" reached lower levels in terms of Acceptance of Perspectives (EMP_PERS) and Empathic Concern (EMP_TROSKA). What is interesting about it is that the respondents who say that they chose the profession by "Coincidence” also achieved significantly higher levels in terms of Acceptance of Perspective compared to those who did not indicate such a reason.

Perceiving empathy as multidimensional, it is assumed that some of its elements are innate. However, empathy can also be developed through life [10]. Thanks to this, there is a justification to put empathy among the effects of education for nursing in the Ordinance of the Ministry of Science and Higher Education from 9th May 2012. [11]

To make the education possible, there is a need for actions to learn about the starting point as well as motivation for starting education are needed.

\section{CONCLUSIONS}

1. The reasons for starting these educational actions among the students of EUH-E from years 2013-2015 do not differ from the reasons declared by nurses who are professionally active at the moment.

2. The level of assertiveness of the people currently starting nursing education at the EHU-E is higher than the level of those who were joining the profession about 20 years earlier.

3. The level of empathy of the surveyed nursing students is similar to the level presented by the older generation of nurses working in hospitals.

4. There are some statistically significant differences between the level of empathy and the reason for choosing that profession. Those who start the education due to the need of helping others, family traditions or by coincidence show a higher level of cognitive empathy. 


\section{To idzie młodość. Nowy wizerunek pielęgniarek i pielęgniarzy}

\section{WPROWADZENIE}

Wykonywanie zawodu pielęgniarki powinno opierać się na głębokim zrozumieniu potrzeb drugiego człowieka. Współcześni adepci pielęgniarstwa rekrutują się jednak z zupełnie innych środowisk w stosunku do osób, które podejmowały naukę na poziomie szkół średnich i należą dzisiaj do przedstawicielek grupy tzw. „średniej wieku pielęgniarki polskiej”.

\section{CEL PRACY}

Główny cel niniejszej pracy stanowiło określenie poziomu kompetencji społecznych studentów pielęgniarstwa na przykładzie studentów I roku Elbląskiej Uczelni Humanistyczno-Ekonomicznej oraz odpowiedź na pytanie jakie motywy skłaniają adeptów zawodu do podjęcia studiów.

\section{MATERIAŁ I METODYKA}

W badaniu uczestniczyło $\mathrm{n}=217$ studentów pielęgniarstwa I roku Elbląskiej Uczelni Humanistyczno Ekonomicznej rozpoczynających naukę w latach 2013-2015.

Do przeprowadzenia badań zastosowano metodę sondażu diagnostycznego. Narzędzia badawcze stanowiły kwestionariusze ankiet: kwestionariusz autorski, Kwestionariusz Wrażliwości Empatycznej autorstwa M. Kaźmierczak, M. Plopa, S. Retowski [1] oraz Kwestionariusz Zachowań Asertywnych autorstwa M. Sobczak opracowany w oparciu o „Mapę asertywności” Marii Król - Fijewskiej [2].

\section{WYNIKI}

Szczegółowa analiza za pomocą testu U Manna Whitney’a ujawniła istotne różnice w zakresie Empatycznej troski (EMP TROSKA) między studentami rocznika 2013 i 2015 oraz rocznika 2014 i 2015. Istotnie wyższy wynik uzyskali studenci rocznika 2015 (p<0,001). W zakresie Empatycznej Przykrości (EMP PRZYKR) istotne różnice ujawniono między studentami rocznika 2014 i 2015 - wyższy wynik uzyskali studenci rocznika 2014. Słabą różnicę statystyczną zanotowano w tym zakresie między rocznikiem 2013 i 2015 ( $\mathrm{p}=0,059)$. Wyższy wynik uzyskali studenci rocznika 2015.W zakresie podskali Przyjmowanie Perspektywy (EMP PERS) istotne różnice stwierdzono między rocznikiem 2013 i 2015 oraz rocznikiem 2014 i 2015. Rocznik 2015 uzyskał w tym zakresie wyższe wyniki ( $\mathrm{p}<0,001 \mathrm{w}$ obu związkach).

W zakresie asertywności istnieje słaba statystycznie różnica między rocznikiem 2013 i 2014 (p=0,084). Studenci z rocznika 2013 mają nieznacznie większy wynik w skali asertywności.

Aby zbadać związki między motywem wyboru studiów a poziomem empatii i asertywności zastosowano nieparametryczny test U Manna-Withney'a.

Osoby wybierające motyw „chęć pomocy innym ludziom” różniły się istotnie w zakresie zmiennej Przyjmowania
Perspektywy (EMP PERS) uzyskując wyższy wynik, niż nie wybierający tego motywu $(\mathrm{U}=4479 ; \mathrm{p}<0,01)$.

- Tab. 1. Charakterystyka badanej grupy ze względu na rok rozpoczęcia studiów i posiadany zawód.

\begin{tabular}{|l|c|c|c|}
\hline \multirow{2}{*}{$\begin{array}{c}\text { Doświadczenie } \\
\text { zawodowe }\end{array}$} & \multicolumn{3}{|c|}{ Rok podjęcia studiów, liczba studentów } \\
\cline { 2 - 4 } & $\mathbf{2 0 1 3}$ & $\mathbf{2 0 1 4}$ & $\mathbf{2 0 1 5}$ \\
\hline Zawód medyczny & 25 & 32 & 37 \\
\hline Zawód niemedyczny & 19 & 18 & 28 \\
\hline Bez zawodu & 26 & 22 & 25 \\
\hline Razem & 70 & 72 & 90 \\
\hline
\end{tabular}

Tab. 2. Poziom asertywności badanych.

\begin{tabular}{|c|c|c|c|c|c|}
\hline 薆 & $\mathbf{N}$ & minimum & maximum & \begin{tabular}{|c|} 
Średnia \\
(wyniki surowe)
\end{tabular} & $\begin{array}{c}\text { Odch. } \\
\text { Standardowe }\end{array}$ \\
\hline 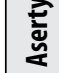 & $\begin{array}{l}\text { (Raw } \\
\text { results) }\end{array}$ & $\begin{array}{l}\text { Standard } \\
\text { deviation }\end{array}$ & 155,00 & 105,5380 & 9,8412 \\
\hline
\end{tabular}

Tab. 3. Poziom empatii badanych.

\begin{tabular}{|l|c|c|c|c|c|}
\hline \multicolumn{1}{|c|}{$\begin{array}{c}\text { Empatia: } \\
\text { podskale }\end{array}$} & $\mathbf{N}$ & minimum & maximum & $\begin{array}{c}\text { Średnia } \\
\text { (sten) }\end{array}$ & $\begin{array}{c}\text { Odch. } \\
\text { Standardowe }\end{array}$ \\
\hline $\begin{array}{l}\text { Empatyczna } \\
\text { troska }\end{array}$ & 204 & 1,00 & 10,00 & 4,1275 & 2,0852 \\
\hline $\begin{array}{l}\text { Empatyczna } \\
\text { przykrość }\end{array}$ & 204 & 1,00 & 10,00 & 4,2304 & 1,6963 \\
\hline $\begin{array}{l}\text { Przyjmowanie } \\
\text { perspektywy }\end{array}$ & 204 & 1,00 & 10,00 & 5,2304 & 1,8677 \\
\hline
\end{tabular}

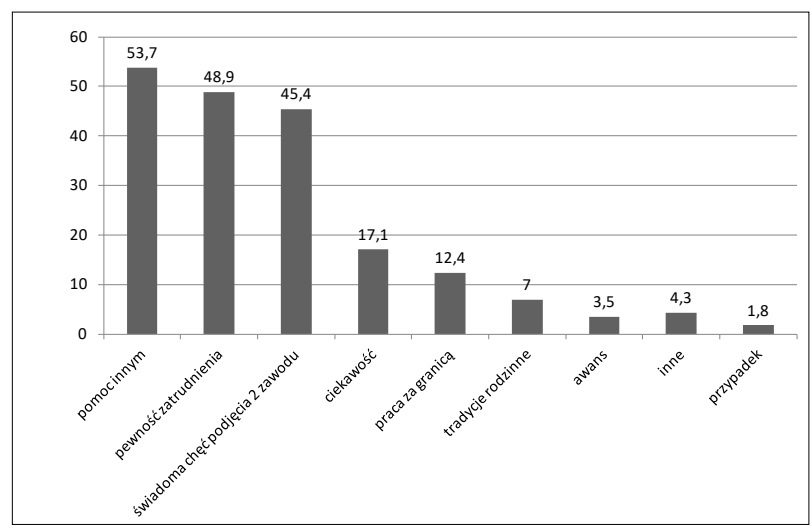

Ryc 1. Motywy wyboru zawodu (n-217).Procent wskazań.

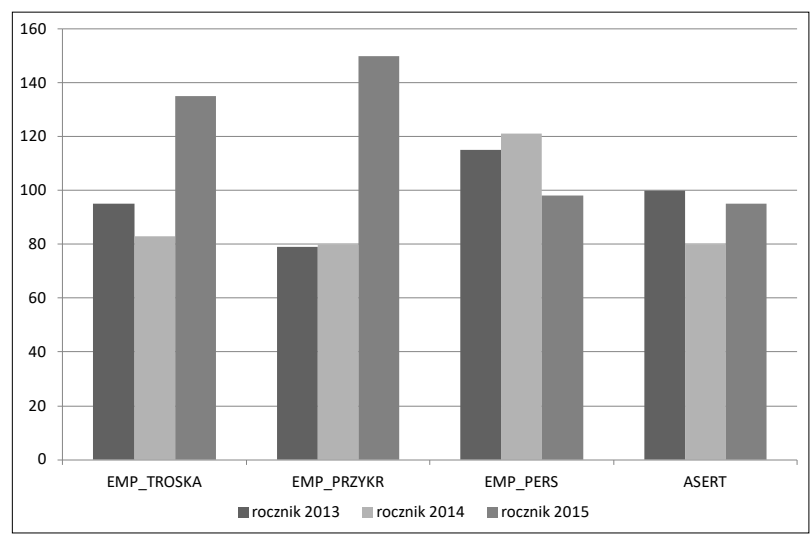

Ryc 2. Różnice w poziomie empatii i asertywności studentów rocznika 2013,2014 i 2015. 
Osoby wybierające zawód pielęgniarki ze względu na pewność zatrudnienia charakteryzują się istotnie niższym poziomem zmiennej Empatyczna Troska (EMP TROSKA) niż osoby niekierujące się tym motywem ( $U=4573$; $\mathrm{p}=0,01)$.

W przypadku motywu „Świadoma chęć posiadania drugiego zawodu" osoby wskazujące na ten motyw uzyskują nieznacznie niższy poziom Przyjmowania Perspektywy (EMP PERS) niż osoby niekierujące się tym motywem $(\mathrm{U}=4739,5 ; \mathrm{p}=0,073)$.

Osoby wybierające zawód ze względu na motyw „Tradycje rodzinne" uzyskują istotnie wyższy wynik w zmiennej Empatyczna Troska (EMP TROSKA) niż osoby nie wybierające tego motywu $(U=871,5 ; p<0,05)$.

Studenci, którzy jako motyw wyboru studiów podali Przypadek" charakteryzują się istotnie wyższym poziomem Empatycznej Troski (EMP TROSKA) niż osoby nie wybierające tego motywu $(\mathrm{U}=61 ; \mathrm{p}=0,081)$.

\section{OMÓWIENIE}

Osoby badane, wybierające studia na kierunku pielęgniarstwo Elbląskiej Uczelni Humanistyczno- Ekonomicznej (EUH-E) w latach 2013-2015 okazały się odmienną grupą, niż pielęgniarki będące obecnie w tak zwanej „Średniej wieku polskiej pielęgniarki” badane dotychczas przez autorki. Wielu z dzisiejszych adeptów posiada już zawód, często jest to inny zawód medyczny jak ratownik medyczny, opiekun medyczny czy położna. Pojawiają się także osoby z zawodami niezwiązanymi z medycyną jak ekonomista, pedagog czy socjolog. Najczęstszym motywem wyboru zawodu ciągle jeszcze jest chęć pomocy innym ludziom. Zarówno młodzi adepci pielęgniarstwa jak i pielęgniarki mające dzisiaj średnio 48 lat deklarują taki właśnie motyw [3].

Asertywność badanych w zakresie średnich wyników jest wyższa, niż studentów EUH-E badanych w roku 2009 i studiujących zaocznie pielęgniarstwo II stopnia, fizjoterapię i ratownictwo medyczne [4]. Oczywiście asertywność nie jest zjawiskiem jednowymiarowym i dopiero analiza poszczególnych sfer asertywności jak wyrażanie swoich uczuć, obrona swoich praw czy skłonność do naruszania cudzych granic może dać większą wiedzę na temat różnic miedzy badanymi osobami.

Empatia badanych studentów w zakresie Empatycznej troski i Empatycznej przykrości nie odbiega od empatii badanych wcześniej pielęgniarek przy użyciu tego samego narzędzia $[5,6,7,8,9]$ i osiąga wartości średnie. Skala Empatycznej troski ocenia w narzędziu skonstruowanym przez autorów Kwestionariusza Wrażliwości Empatycznej [2] umiejętność współodczuwania i współczucia wobec ludzi dotkniętych niepowodzeniem.. Empatyczna przykrość dotyczy zaś odczuwania przykrych wrażeń i dyskomfortu związanych $\mathrm{z}$ obserwowaniem cierpienia innych ludzi. Zarówno Empatyczna troska jak i Empatyczna przykrość stanowią emocjonalny wymiar empatii. Przyjmowanie Perspektywy natomiast dotyczy skłonności przyjmowania punktu widzenia innych ludzi w codziennych sytuacjach i odnosi się do poznawczego aspektu empatii. [2]
Wymiar Przyjmowania perspektywy u pielęgniarek badanych w 2011 roku $[5,6]$ osiągał poziomy wysokie, podczas gdy u osób podejmujących aktualnie studia osiąga wartości średnie. Wyniki przeprowadzonych badań wykazują ciekawe, istotne statystycznie różnice w poziomie empatii studentów EUH-E rocznika 2013, 2014 i 2015. Studenci podejmujący naukę w roku akademickim 2015/2016 wykazali się wyższym poziomem Empatycznej Troski i Przyjmowaniem Perspektywy, niż studenci wcześniejszych roczników. Być może ma to związek z dotychczasowymi doświadczeniami zawodowymi tych osób. Uzyskane wyniki pokazują również że motywy wyboru zawodu z pobudek emocjonalnych , takich jak „chęć pomocy innym ludziom” czy "tradycje rodzinne” mają istotny związek z empatią w zakresie Przyjmowania Perspektywy (EMP PERS). Osoby wskazujące ten motyw osiągały znacząco wyższe wyniki w tym zakresie. Studenci, którzy wskazywali na ekonomiczne motywy wyboru zawodu takie jak: „pewność zatrudnienia” czy „świadoma chęć posiadania drugiego zawodu" osiągnęły niższe poziomy w zakresie Przyjmowania Perspektywy (EMP PERS) oraz Empatycznej Troski (EMP TROSKA). Co ciekawe, badani którzy twierdzą, że zawód wybrali „z przypadku” osiągali także istotnie wyższy poziom w zakresie Przyjmowania Perspektywy w stosunku do osób, które nie wskazały takiego powodu.

Pojmując empatię wielowymiarowo przyjmuje się, że pewne jej elementy są wrodzone. Empatię można jednak także kształtować i rozwijać [10]. Znajduje to uzasadnienie umieszczenia empatii wśród efektów kształcenia dla kierunku pielęgniarstwo Rozporządzeniu Ministra Nauki i Szkolnictwa Wyższego z dnia 9 maja 2012 roku [11].

Aby takie kształcenie było możliwe potrzebne są działania zmierzające do poznania punktu wyjściowego oraz motywacji podejmowania kształcenia.

\section{WNIOSKI}

1. Motywy podejmowania kształcenia przez studentów EUH-E z lat 2013-2015 nie odbiegają od motywów deklarowanych przez pielęgniarki aktualnie wykonujące ten zawód.

2. Poziom asertywności osób podejmujących aktualnie kształcenie na kierunku pielęgniarstwo w EUH-E jest wyższy, niż osób przystępujących do zawodu około 20 lat wcześniej.

3. Poziom empatii badanych adeptów pielęgniarstwa jest zbliżony do poziomu prezentowanego przez pielęgniarki starszego pokolenia pracujących w szpitalach.

4. Istnieją istotne statystycznie różnice między poziomem empatii a motywem wyboru zawodu. Osoby podejmujące kształcenie z powodu chęci pomocy innym, tradycji rodzinnych i z przypadku wykazują wyższy poziom empatii poznawczej. 


\section{PIŚMIENNICTWO/REFERENCES}

1. Król-Fijewska M. Stanowczo, łagodnie, bez lęku. Warszawa: Wydawnictwo WAB; 2003.

2. Kaźmierczak M., Plopa M., Retowski S. Skala Wrażliwości Empatycznej. Przegląd Psychologiczny. 2007; 50(1): 9-24.

3. Sobczak M. Empatia i asertywność wobec wypalenia zawodowego pielęgniarek. Niepublikowana praca doktorska. Collegium Medicum im. Ludwika Rydygiera w Bydgoszczy, 2008

4. Sobczak M. Poziom asertywności studentów Wydziału Nauk o Zdrowiu Elbląskiej Uczelni Humanistyczno-Ekonomicznej. [w:] Plopa M, red. Człowiek u Progu Trzeciego Tysiąclecia. Zagrożenia i Wyzwania. Wydawnictwo Elbląska Uczelnia Huamnistyczno-Ekonomiczna, Tom 3; 2009.

5. Dziuba C. Empatia i asertywność pielęgniarek podstawowej opieki zdrowotnej powiatu elbląskiego. Niepublikowana praca magisterska pod kierunkiem Marzeny Sobczak. Elbląska Uczelnia Humanistyczno-Ekonomiczna; 2011.

6. Bartoszewska K. Empatia i asertywność wśród pielęgniarek Uniwersyteckiego Centrum Klinicznego w Gdańsku. Niepublikowana praca magisterska pod kierunkiem Marzeny Sobczak. Elbląska Uczelnia Humanistyczno-Ekonomiczna; 2011.

7. Zielińska A. Asertywność i empatia pieleggniarek oddziałów zabiegowych Wojewódzkiego Szpitala Specjalistycznego im. Janusza Korczaka w Słupsku. Niepublikowana praca magisterska pod kierunkiem Marzeny Sobczak. Elbląska Uczelnia Humanistyczno-Ekonomiczna; 2011.
8. Zielińska N. Asertywność i empatia pielęgniarek oddziałów zachowawczych Wojewódzkiego Szpitala Specjalistycznego im. Janusza Korczaka w Słupsku. Niepublikowana praca magisterska pod kierunkiem Marzeny Sobczak. Elbląska Uczelnia Humanistyczno-Ekonomiczna; 2011.

9. Ślęzak B. Empatia i asertywność pielęgniarek Stacji Dializ. Niepublikowana praca magisterska pod kierunkiem Marzeny Sobczak. Elbląska Uczelnia HumanistycznoEkonomiczna; 2011

10. Davis M. H. Empatia. 0 umiejętności współodczuwania. Gdańsk: Gdańskie Wydawnictwo Psychologiczne; 2001.

11. Rozporządzenie Ministra Nauki i Szkolnictwa Wyższego z dnia 9 maja 2012 roku w sprawie standardów kształcenia dla kierunków: lekarskiego, lekarsko dentystycznego, farmacji , pielęgniarstwa i położnictwa. Dz.U. z dnia 5 czerwca 2012, poz.631.

Praca przyjęta do druku/Manuscript received: 15.07.2016

Praca zaakceptowana do druku/Manuscript accepted: 11.11.2016

Tłumaczenie/Translation: Marlena Kardasz 